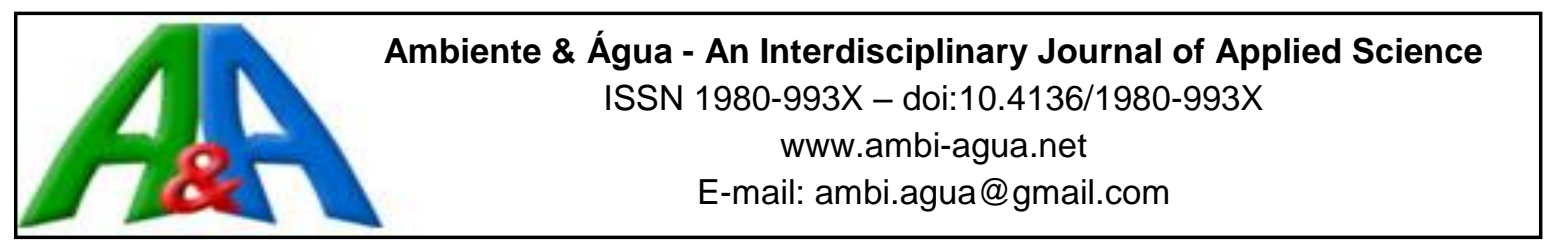

\title{
Frequency of mentum deformity in Chironomus sancticaroli (Diptera: Chironomidae) in a laboratory culture
}

\author{
ARTICLES doi:10.4136/ambi-agua.2337
}

Received: 01 Oct. 2018; Accepted: 01 Feb. 2019

\begin{abstract}
Mariana Silveira Guerra Moura e Silva ${ }^{1 *}$; Ana Lúcia Silva MarigoĐ; William Viveiros ${ }^{3}$ id ; Mônica Luisa Kuhlmann ${ }^{3}$

${ }^{1}$ Embrapa Meio Ambiente (EMBRAPA), Jaguariúna, SP, Brasil

Laboratório de Ecossistemas Aquáticos. E-mail: mariana.silveira@embrapa.br

${ }^{2}$ Universidade Estadual de Campinas (UNICAMP), Campinas, SP, Brasil

Instituto de Geociências (IGE). E-mail: analuciamarigo@yahoo.com.br

${ }^{3}$ Companhia Ambiental do Estado de São Paulo (CETESB), São Paulo, SP, Brasil

Divisão de Análises Hidrobiológicas. E-mail: wviveiros@sp.gov.br, mkuhlmann@sp.gov.br

*Corresponding author
\end{abstract}

\begin{abstract}
The midge Chironomus sancticaroli (Diptera: Chironomidae) has been used in ecotoxicological tests because it is sensitive to a variety of inorganic pollutants. Among the parameters used to evaluate the toxicity of a substance is the frequency of mentum deformity, which is part of the oral system of this organism. However, there is still no consensus on the baseline level (percentage) of acceptable deformities in laboratory cultures not exposed to pollutants. The determination of this variable is important to ensure the validity of bioassays and to compare cultures from different research and teaching institutions. Once this value is established, it will also be used to monitor the quality of organisms cultured, since factors such as inbreeding could increase the frequency of mentum deformity. Thus, the objective of this study was to quantify the percentage of mentum deformity in the fourth instar of $C$. sancticaroli larvae from the culture of the Laboratory of Aquatic Ecosystems, at Embrapa Meio Ambiente. The average frequency of mentum deformity obtained was $6,63 \%$. It is believed that factors such as the renewal of the culture with the inclusion of spawns from the laboratories of other institutions, as well as the control of the quality of the dilution water and the sediment of the breeding may have contributed to a low frequency of mentum deformity of the culture observed in this study.
\end{abstract}

Keywords: bioindicator, ecotoxicology, inbreeding.

\section{Estudo para determinação da frequência de deformidade do mento em Chironomus sancticaroli (Diptera: Chironomidae) em cultura de laboratório}

\section{RESUMO}

A espécie Chironomus sancticaroli (Diptera: Chironomidae) tem sido utilizada em testes ecotoxicológicos por ser sensível a uma variedade de poluentes inorgânicos. Um dos parâmetros utilizados para avaliar a toxicidade de uma substância é a frequência de deformidade 
do mento, que faz parte do sistema oral deste organismo. Entretanto, ainda não há consenso a respeito do nível basal (porcentagem) de deformidade aceitável em culturas de laboratório não expostas a poluentes. A determinação desta variável é importante para assegurar a validade de bioensaios e comparar culturas de diferentes instituições de pesquisa e ensino. Uma vez estabelecido, este número também será usado para o controle da qualidade dos organismos criados, já que fatores como o endocruzamento poderiam aumentar a frequência de deformidade do mento. Assim, o objetivo deste estudo foi quantificar a porcentagem de deformidade do mento em larvas de quarto instar de $C$. sancticaroli de cultura do Laboratório de Ecossistemas Aquáticos da Embrapa Meio Ambiente. A média de frequência de deformidade obtida para a cultura foi de $6,63 \%$. Acredita-se que fatores como a renovação da cultura com a inclusão de desovas de laboratórios de outras instituições, assim como o controle da qualidade da água de diluição e do sedimento da criação, podem ter contribuído para uma baixa frequência de deformidade do mento da cultura.

Palavras-chave: bioindicadores, ecotoxicologia, endocruzamento.

\section{INTRODUCTION}

Aquatic insects of the family Chironomidae (Diptera) are widely used as bioindicators of environmental impacts, because their entire larval cycle occurs in sediment, where they interact with contaminants that tend to accumulate in this compartment of the aquatic ecosystem. Furthermore, they are ubiquitous in distribution, sensitive to various pollutants and present a relatively short life cycle, being ideal candidates for ecotoxicological studies (Park and Choi, 2009). They are also indicated for ecotoxicological studies because they present rapid responses and easy manipulation of the cultures (USEPA, 2000; OECD, 2007). They present varieties of feeding habits, from the filtration of particles in the water column to the predation of small organisms.

The genus Chironomus (Diptera, Chironomidae) is an organism of great importance in the group of benthic bioindicators. It plays a relevant role in the food chain and in sediment nutrient cycling. Further, it is easily cultured in the laboratory. Its larval cycle is aquatic, in direct contact with the sediment, where it remains buried. The life cycle of the individuals of the genus Chironomus comprises four phases: egg, larval period (4 stages), pupa, and adult. Soon after the egg hatches, in the first stage, the larva remains between the sediment particles and feeds on detritus (Chironomus is classified as a gathering collector), but can also be planktonic. From the second stage, the larvae construct cocoons that shelter them and increase in size, until reaching the stage of pupa and soon after, adult, which is terrestrial (Bonani, 2010). They are found in most aquatic environments and can be very tolerant to extreme environmental conditions such as variations in $\mathrm{pH}$, temperature, dissolved oxygen, salinity, depth, and speed of currents. In order to survive in habitats with low concentrations of dissolved oxygen, the larvae present hemoglobin, which gives it a reddish coloration, long abdominal gills and undulating movement (Viveiros, 2012).

Sanseverino and Nessimian (2008) describe that several genera of the family Chironomidae are reported in studies of deformities, and the genus Chironomus (Meigen 1803) is the most-cited. Comparing the incidence of deformities in many genera of Chironomidae in Canadian lakes, Hudson and Ciborowski (1996b) suggested Chironomus, Phaenopsectra and Procladius because of their wide distribution and sensitivity to the formation of deformities. In the cephalic capsules of the larvae of Chironomus several sensorial structures and mouthparts are inserted; one of them is the mentum. They are composed of chitin which is a biological component of high strength.

Chironomus may present deformities in mentum when exposed to radiation-contaminated

Rev. Ambient. Água vol. 14 n. 2, e2337 - Taubaté 2019 
sediments (Williams et al., 2001), heavy metals (Callisto et al., 2000; Deliberalli et al., 2018), pesticides (Hamilton and Saether, 1971), among others. These same authors report high frequencies of deformity in the chironomids in their different larval instars, evidencing such structure as one of the most sensitive and important for use in biomonitoring. Such deformities can be of different types and intensities, including lack or excess of teeth, gap, bifurcation of the central tooth, asymmetry, wear and break. To apply the metric as a quality criterion, CETESB (2017) standardized the data acquisition in order to minimize subjectivity considering as deformities missing and excessive teeth, Kohn gap and bifurcation of the central tooth. In these field studies, deformity is observed as an effect of toxic substances, however, there is no national or international standard protocol for its use as an endpoint in ecotoxicological bioassay (Viveiros, 2012).

At the individual level, deformities do not impair emergency, but they decrease body size and retard development. Further bioaccumulation may occur in deformed individuals. Individual differences reflect microhabitat conditions and genetic differences linked to resistance mechanisms (Janssens de Bisthoven et al., 1998). Studies suggest that some types of deformity are related to the inbreeding and age of laboratory-maintained creations (Vogt et al., 2013). Besides that, there are few published studies with $C$. sancticaroli for deformity in culture. However, there is no consensus on the rate of acceptable baseline deformity in laboratory for Chironomus cultures. These data are important for the assessment of test organism fitness before their use in ecotoxicological tests in order to determine the level of deformity.

This study evaluated the incidence of mentum deformities in individuals of Chironomus sancticaroli in cultures maintained in the Laboratory of Aquatic Ecosystems at Embrapa Meio Ambiente.

\section{MATERIAL AND METHODS}

\subsection{Culture conditions:}

C. sancticaroli egg masses from Laboratory of Aquatic Ecosystems (LEA) - Embrapa Meio Ambiente were placed into plastic trays of approximately 30 x 37 x $8 \mathrm{~cm}$ containing $\sim 1$ $\mathrm{cm}$ of sand washed and calcinated in muffle for total elimination of organic matter (Dornfeld, 2006). The water used was sterilized and reconstituted in the laboratory (Jonsson and Maia, 1999), with controlled aeration and temperature $\left(25^{\circ} \mathrm{C} \pm 1{ }^{\circ} \mathrm{C}\right)$ and photoperiod $12 \mathrm{~h}$ light $/ 8 \mathrm{~h}$ dark. The water column was aerated through porous stone and air mini compressor. The newly hatched larvae were fed once daily with Tetramin ${ }^{\circledR}$, according to the concentration indicated in Fonseca and Rocha (2004) until reaching the last larval stage ( $4^{\text {th }}$ instar).

\subsection{Bioassay procedures:}

After reaching the 4th instar, 454 larvae were randomly separated, on different dates, from the same culture to prepare microscope slides with the cephalic capsules, with an average size of $0.32 \pm 0.02 \mathrm{~mm}$, corresponding to this larval stage, according to Strixino and Strixino (1982). The cephalic capsule was separated from the larvae body using a fine-pointed forceps and mounted in slides with ventral part upward in the Hoyer medium. That medium is composed of gum arabic, chloral hydrate, glycerol and water and is used to make semi-permanent slide mounts for examination of the cephalic capsule under microscope. For the calculation of deformity frequencies, mentum was considered deformed when presenting: exceeding or missing teeth, central teeth bifurcation or Kohn gap. The last one is a type of deformity where a cavity is formed in the tooth. It differs from a break by having smooth edges. The frequency of deformities was expressed as a percentage of the total of analyzed larvae. Four batches of larvae were analyzed under the same laboratory conditions at different dates: 10/04/17; $11 / 06 / 17$ e $12 / 07 / 17$ and 12/12/18.

Rev. Ambient. Água vol. 14 n. 2, e2337 - Taubaté 2019 


\section{RESULTS AND DISCUSSION}

A total of 454 fourth instar larvae of Chironomus sancticaroli from the Laboratory of Aquatic Ecosystems of Embrapa Meio Ambiente were analyzed, and an average frequency of $6.63 \%$ of mentum deformity was found (Figure 1). The types of deformity found were: "missing teeth", "excess teeth", "gap" and "central tooth bifurcation" (Figure 1).

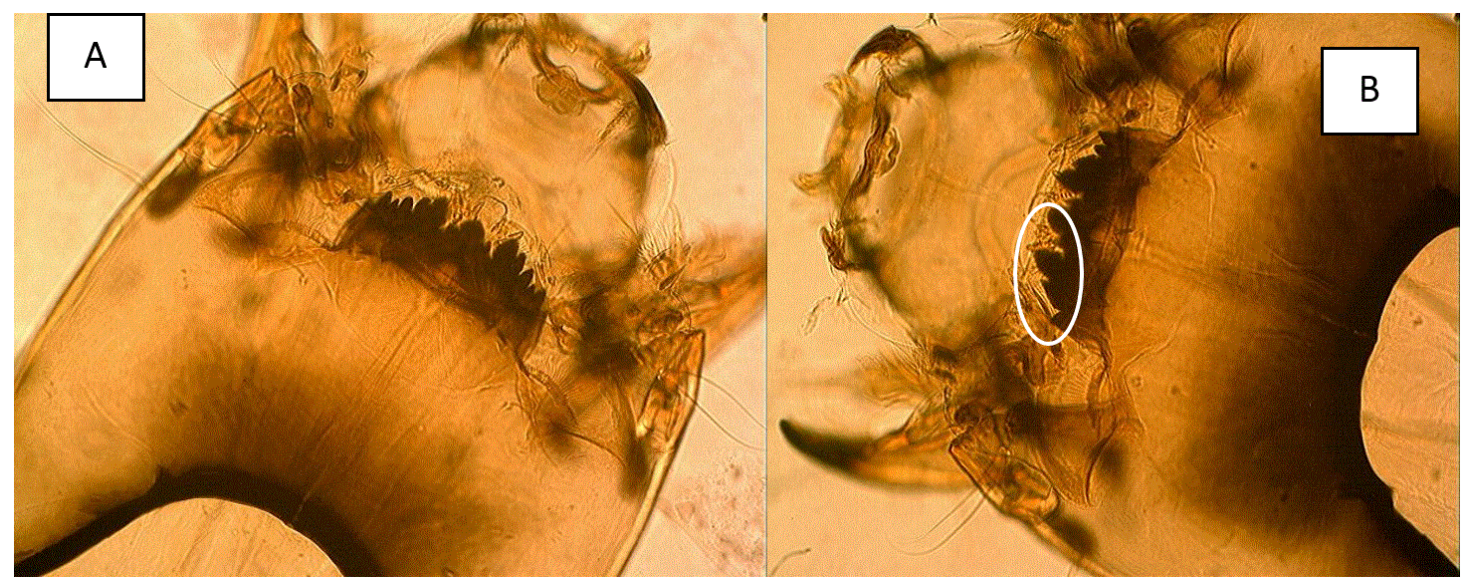

Figure 1. Example of mentum deformity found at Chironomus sancticaroli culture from Laboratory of Aquatic Ecosystems, at Embrapa Meio Ambiente. Normal tooth (A) and mentum with absence of lateral teeth deformity type (B). Microscope amplification of 100x.

For field data (larvae in the natural environment), Burt et al. (2003) defined the frequency of deformities on Chironomus population collected in reference sites of the Great Lakes as $2.1 \pm 0.2 \%$, but the authors considered that for rivers, streams and bogs the basal value could be less than $1 \%$. Hudson and Ciborowski (1996b) also observed smaller percentages of mentum deformity at sites considered as "reference" ones (not impacted). Considering the quality criteria stated by CETESB (CETESB, 2017), frequencies above $6 \%$ mean that the site has bad quality and probably receives chemical contaminants. In laboratory assays, larger percentages than the present study have been observed in control condition. In test control, Hudson and Ciborowski (1996a) observed until 7.4\% of deformity for $C$. salinarius; a very similar result (until 7.3\%) was obtained by Arambourou and coworkers (2015) for C. riparius; Kwak and Lee (2005) found $18.2 \%$ for C. plumosus, Bonani (2010), when exposing organisms of $C$. sancticaroli to the test control sediment obtained a mean deformity of $20.2 \%$ and $13 \%$ at Viveiros (2012). On the other hand, Dornfeld (2006); evaluating the toxicity of cadmium and copper in $C$. xanthus assays, observed only $2.0 \%$ deformity in control larvae. In laboratory culturing, Rebechi and Silva (2012) observed 9\% of mentum deformity in C. sancticaroli (instar II) reared in standard conditions and $48 \%$ in III instar, while Viveiros (2012) observed an average of $13 \%$ for the same specie (IV instar). Despite these data, the criteria used for field studies should not be applied directly to laboratories tests, because the environmental conditions are different.

Long time chironomid cultures generally exhibit high levels of inbreeding, and this could impact the reliability of ecotoxicological tests using this strains. The introduction of new cultures from other laboratories, and also the use of field-collected strains are alternatives to reduce inbreeding (Nowak et al., 2007).

Vogt et al. (2013) and Bird et al. (1995) have highlighted the importance of inbreeding in the level of mouthpart deformities in C. riparius larvae. According to them, unpredictable environmental variables may have a greater influence on the approach to field studies, whereas population effects (e.g. inbreeding) may be more pronounced in laboratory studies. These same authors observed a direct relation between the increase of deformities of the mentum in $C$. 
riparius with the increase of inbreeding. Sanseverino and Nessimian (2008) mentioned increased central tooth deformities in the 4th and 6th generations of their cultures, associating the fact with inbreeding. Thus, field populations of $C$. riparius have greater genetic diversity than the laboratory populations, being less subject to the deformity of the mentum induced by the stressors. Vermeulen et al. (2000) also found a high incidence of deformities in their cultures and in the controls of their tests (from 34 to 56\%) and concluded that the crossing between relatives in the cultures is the main thing responsible for the high indexes found. The same condition was observed by Bird (1997) and Janssens de Bisthoven (2001) including the organisms age and no renovation of the cultures. Culture condition can also promote deformities, as observed by Madden et al. (1992). These researchers obtained high deformity frequencies $(20-46 \%)$ in larvae maintained in artificial substrate (Martin's solution) but diminished frequency (19\%) when natural water was used in the culture. On the other hand, Dickman et al. (1992) observed a reduction of mentum deformity in organisms maintained in a clean sediment after collecting them in contaminated sites with HPA's. According to Jeyasingham and Ling (1997), the origin of the organisms and the substrate that is used in the cultures can influence the frequencies of mentum deformity, but it is possible to reduce them until F2 generation.

Further study still has to be performed in order to define if the level of deformity found is in this experiment can be considered low, and if it may be related to the fact that the culture of Embrapa Meio Ambiente received spawnings from other institutions, reducing inbreeding within the population. A further aspect in this context concerns inheritance. The insertion of new spawns, preferably from other laboratories, also brings the advantage of renewing culture from the point of view of its age. Sanseverino and Nessimian (2008) observed that the presence of some mentum deformities (split of median tooth, multiple teeth) was related to the age of the culture for Chironomus tentans, because of inbreeding.

In addition, the control of water and sediment quality variables (using reconstituted water and calcinated sand) may contribute to the low percentage of deformity found. Nevertheless, it is important to evaluate and monitor the fluctuation of the deformity in this culture in order to be able to use this parameter (frequency of mentum deformity) in assessment of the health of organisms and for detecting the need for culture renewal.

\section{CONCLUSIONS}

The cultures of Chironomus sancticaroli of Embrapa Meio Ambiente showed low frequency of deformities when compared to other studies, suggesting that the procedures developed have been effective in prevent inbreeding effects.

Evaluating and monitoring the fluctuation of mentum deformity in laboratory culture is important in order to be able to use this parameter in the evaluation of the health of the organisms and to detect the need for culture renewal.

Further studies are required in order to define the acceptable level of deformity in Chironomus sancticaroli raised in laboratory which can ensure the reliability of the culture.

It is interesting to perform genetic tests to quantify inbreeding among insect populations cultured in laboratory.

\section{REFERENCES}

ARAMBOUROU, H.; BRANCHU, P.; BEISEL, J-N. Increase in Developmental Instability in a Field-Collected Chironomus Population Maintained Under Laboratory Conditions. Bulletin of Environmental Contamination Toxicology, v. 94, p. 681-687, 2015. https://doi.org/10.1007/s00128-015-1497-5 
BIRD, G. A.; SCHWARTZ, W. J.; JOSEPH, D. L. The effect of $210 \mathrm{~Pb}$ and lead on the induction of mental deformities in Chironomus tentans larvae and on their growth and survival. Environmental Toxicology and Chemistry, v. 14, n. 12, p. 2125-2130, 1995. https://doi.org/10.1002/etc.5620141216

BIRD, G. A. Deformities in cultured Chironomus tentans larvae and the influence of substrate on growth, survival and mentum wear. Environmental Monitoring and Assessment, v. 45, p. 273-283, 1997. https://doi.org/10.1023/A:1005782803930

BONANI, F. Avaliação de deformidades morfológicas em larvas de Chironomus (Diptera, Chironomidae) na bacia do rio Piracicaba e sua aplicação no biomonitoramento. 2010. 80f. Dissertação (Mestrado em Ecologia e Recursos Naturais) - Centro de Ciências Biológicas e da Saúde, Universidade Federal de São Carlos, São Carlos, 2010.

BURT, J.; CIBOROWSKI, J. J. H.; REYNOLDSON, T. B. Baseline incidence of Mouthpart Deformities in Chironomidae (Diptera) From The Laurentian Great Lakes, Canadá. Journal of Great Lakes Research, v. 29, n. 1, p. 172-180, 2003. https://doi.org/10.1016/S0380-1330(03)70425-0

CALliSTO, M.; MARQUES, M. M.; BARBOSA, F. A. Deformities in larval Chironomus (Diptera, Chironomidae) from the Piracicaba river, southeast Brazil. SIL Proceedings, 1922-2010, v. $27, \quad$ n. $5, \quad$ p. $2699-2702, \quad$ https://doi.org/10.1080/03680770.1998.11898157

COMPANHIA AMBIENTAL DO ESTADO DE SÃO PAULO. Qualidade das Águas Superficiais no Estado de São Paulo 2016. São Paulo: CETESB, 2017.

DELIBERALLI, W.; CANSIAN, R. L.; PEREIRA, A. A. M.; LOUREIRO, R. F.; HEPP, L. U.; RESTELLO, R. M. The effects of heavy metals on the incidence of morphological deformities in Chironomidae (Diptera). Zoologia, v. 35, p. 1-7, 2018. http://dx.doi.org/10.3897/zoologia.35.e12947

DICKMAN, M.; BRINDLE, I.; BENSON, M. Evidence of teratogens in sediments of the Niagara river watershed as reflected by chironomid (Diptera: Chironomidae) deformities. Journal of Great Lakes Research, v. 18, n. 3, p. 467-480, 1992. https://doi.org/10.1016/S0380-1330(92)71312-4

DORNFELD. C. B. Utilização de Chironomus sp (Diptera: Chironomidae) para avaliação da qualidade de sedimentos e contaminação por metais. 2006. Tese (Doutorado) Escola de Engenharia de São Carlos, Universidade de São Paulo, São Carlos, 2006.

FONSECA, A. L.; ROCHA, O. Laboratory cultures of the native species Chironomus xanthus Rempel, 1939 (Diptera: Chironomidae). Acta Limnologica Brasiliensia, v. 16, n. 2, p. 153-161, 2004.

HAMILTON, A. L.; SAETHER, O. A. The occurrence of characteristic deformities in the chironomid larvae of several Canadian lakes. Canadian Entomologist, v. 103, p. 363368, 1971. https://doi.org/10.4039/Ent103363-3

HUDSON, L. A.; CIBOROWSKI, J. H. Teratogenic and genotoxic responses of larval Chironomus salinarius group (Diptera: Chironomidae) to contaminated sediment. Environmental Toxicology and Chemistry, v. 15, n. 8, p. 1375-1381, 1996a. https://doi.org/10.1002/etc.5620150817 
HUDSON, L. A.; CIBOROWSKI, J. H. Spatial and taxonomic variation in incidence of mouthpart deformities in midge larvae (Diptera: Chironomidae: Chironomini). Canadian Journal of Fisheries and Aquatic Sciences, v. 53, p. 297-304, 1996 b. https://doi.org/10.1139/f95-199

JANSSENS DE BISTHOVEN, L.; NUYTS, P.; GODDERIS, B.; OLLEVIER, F. Sublethal parameters in deformed Chironomus larvae: clues to understanding their biomarker value. Freshwater Biology, v. 39, n. 1, p. 179-191, 1998. https://doi.org/10.1046/j.13652427.1998.00265.x

JANSSENS DE BISTHOVEN, L.; POSTMA, J.; VERMEULEN, A.; GOEMANS, G.; OLLEVIER, F. Morphological deformities in Chironomus riparius Meigen larvae after exposure to cadmium over several generations. Water, Air and Soil Pollution, v. 129, p. 167-179, 2001. https://doi.org/10.1023/A:1010367524314

JEYASINGHAM, K.; LING, N. Head capsule deformities in Chironomus zealandicus (Diptera: Chironomidae): influence of site and substrate. New Zealand Journal of Marine and $\begin{array}{llllll}\text { Freshwater } & \text { Research, } & \text { v. } & 31, & \text { p. }\end{array}$ https://doi.org/10.1080/00288330.1997.9516756

JONSSON, C. M.; MAIA, A. H. N. Protocolo de avaliação de agentes microbianos de controle de pragas para registro como biopesticidas. Testes tóxico patológicos em organismos não alvo do ambiente aquático: organismos zooplanctônicos, fitoplanctônicos e vertebrados. Jaguariúna: Embrapa Meio Ambiente, 1999. (Documentos, v. 11).

KWAK, I. S.; LEE, W. Mouthpart Deformity and Developmental Retardation Exposure of Chironomus plumosus (Diptera: Chironomidae) to Tebufenozide. Bulletin of Environmental Contamination and Toxicology, v. 75, n. 5, p. 859-865, 2005. https://doi.org/10.1007/s00128-005-0829-2

MADDEN, C. P.; SUTER, P. J.; NICHOLSON, B. C.; AUSTIN, A. D. Deformities in Chironomid larvae as indicators of pollution (pesticide) stress. Netherlands Journal of Aquatic Ecology, v. 26, n. 2-4, p. 551-557, 1992. https://doi.org/10.1007/BF02255289

NOWAK C, VOGT C, DIOGO B, SCHWENK K. Genetic impoverishment in laboratory cultures of the test organism Chironomus riparius. Environmental Toxicology and Chemistry, v. 26, p. 1018-1022, 2007. https://doi.org/10.1897/06-349R.1

OECD. Test No. 225: Sediment-water Lumbriculus toxicity test using spiked sediment. OECD Guideline for the Testing of Chemicals. Paris, 2007.

PARK, S.Y.; CHOI, J. Genotoxic effects of nonylphenol and bisphenol exposure in aquatic biomonitoring species: Freshwater crustacean, Daphnia magna, and aquatic midge, Chironomus riparius. Bulletin of Environmental Toxicology and Chemistry, v. 83, p. 463-468, 2009. https://doi.org/10.1007/s00128-009-9745-1

REBECHI, D.; SILVA, M. N. Setting the reference for the use of Chironomus sancticaroli (Diptera: Chironomidae) as bioindicator: Ontogenetic pattern of larval headstructures. Zoologia, v. 29, n. 2, p. 167-171, 2012.

SANSEVERINO, A. M.; NESSIMIAN, J. L. Assimetria Flutuante em Organismos Aquáticos e sua Aplicação para Avaliação de Impactos Ambientais. Oecologia Brasiliensis, v. 12, n. 3, p. 382-405, 2008.

STRIXINO, S. T.; STRIXINO, G. Ciclo de Vida de Chironomus sancticaroli (Diptera, Chironomidae). Revista Brasileira de Entomologia, v. 26, n. 2, p. 183-189, 1982. 
USEPA. Methods for measuring the toxicity and bioaccumulation of sediment-associated contaminants with freshwater invertebrates. EPA 600/R-99-064. Duluth, 2000.

VERMEULEN, A. C.; LIBERLOO, G.; DUMONT, P.; OLLEVIER, F.; GODDEERIS, B. Exposure of Chironomus riparius larvae (Diptera) to lead, mercury and $\beta$-stosterol: effects on mouthpart deformation and moulting. Chemosphere, v. 41, p. 1581-1591, 2000. https://doi.org/10.1016/S0045-6535(00)00033-3

VIVEIROS, W. Chironomus sancticaroli: do cultivo em laboratório ao ensaio ecotoxicológico com amostras ambientais de sedimento. 2012. 91 f. Dissertação (Mestrado em Ciências na Área de Tecnologia Nuclear - Materiais) - Instituto de Pesquisas Energéticas e Nucleares, Universidade de São Paulo, São Paulo, 2012.

VOGT, C.; LANGER-JAERICH, M.; ELASSER, O.; SCHMIDT, C.; VAN DONGEN, S.; KOHLER, H.; OEHLMANN, J.; NOWAK, C. Effects of inbreeding on mouthpart deformities of Chironomus riparius under sublethal pesticide exposure. Environmental

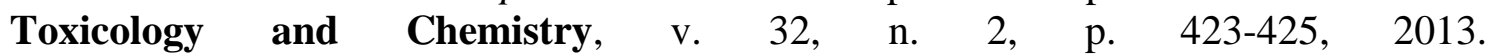
https://doi.org/10.1002/etc.2071

WILliams, D. D.; NESTEROVITCH, A. I.; TAVARES, A. F.; MUZZATTI, E. G. Morphological deformities occurring in Belarusian chironomids (Diptera: Chironomidae) subsequent to the Chernobyl nuclear disaster. Freshwater Biology, v. 46, p. 503-512, 2001. https://doi.org/10.1046/j.1365-2427.2001.00699.x 